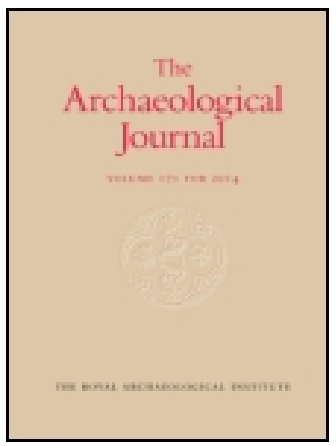

Archaeological Journal

\title{
An Unknown Sixteenth Century Topography of Rome
}

\section{Thomas Ashby D.Litt., F.S.A.}

To cite this article: Thomas Ashby D.Litt., F.S.A. (1908) An Unknown Sixteenth Century Topography of Rome, Archaeological Journal, 65:1, 245-264, DOI: 10.1080/00665983.1908.10853084

To link to this article: http://dx.doi.org/10.1080/00665983.1908.10853084

曲 Published online: 17 Jul 2014.

Submit your article to this journal $[\pi$

Џll Article views: 3

Q View related articles $๘$ 


\title{
AN UNKNOWN SIXTEENTH CENTURY TOPOGRAPHY OF ROME. ${ }^{1}$
}

\author{
By THOMAS ASHBY, D.LitT., F.S.A.
}

In the summer of $1906 \mathrm{I}$ had the good fortune to visit the extensive and valuable library of Mr. C. W. Dyson Perrins at Malvern. I found among the books that he had recently acquired was a volume that I had myself seen (but failed to buy) at the sale of Sir A. Fountain's books, at Messrs. Sotheby, Wilkinson, and Hodge's in June, 1902. It was there purchased by Messrs. Pickering and Chatto, the well-known booksellers, who sold it to Mr. Corfield; and at his sale it was acquired by Mr. Perrins.

The earlier history of the volume is not known to me. The leaves are of vellum, and used on both sides, the size of the single page being 248 by $200 \mathrm{~mm}$. : but many of the drawings are on the double page; and from the existence of a fragmentary marginal contents note on f. $8^{v}$, we may infer that the leaves have been cut. From the sumptuous "get-up" of the volume it may legitimately be supposed that it was made, not for the press, but for presentation to some wealthy patron of the artist and author. The drawings have elaborate ornamental borders, especially some of those on the double page, as will be seen in the illustrations. It has a fine French binding, possibly an actual work of Grolier, but this may have originally been made for some other work. For the book is by no means complete, as is clear from the earlier numbering on the leaves (on one side only) and from the fragments of text which are found on the back of some of the leaves, which have in those cases been gummed together, so that only the drawings are visible-a sure indication that at one time it passed into the hands of a collector who cared only for the drawings, and who must have destroyed the greater part of the

1 Read before the Meeting of the Institute on July 1st, 1908. 
text, which had no drawings interspersed with it. $\mathrm{He}$ then renumbered the leaves on both sides, from 1 to 62 , taking no notice of course of the sides on which there was text, which were gummed together. It seems clear from the earlier numbering, as given in the list of contents at the end of this paper, that we may infer that from $f$. 15 onwards (which must have borne the earlier number 94) to the end there was no more text, but nothing but views on both sides of the page; so that f. 38 , which bore the number 117, was the last numbered page of the book. The title page is decorated with an architectural back-ground, in front of which stand the figures of St. Peter and St. Paul, on each side of the tablet containing the title. This has been cut out, and a label of parchment substituted-

$$
\begin{gathered}
\text { DISEGNI.DE } \\
\text { LE RVINE DI RO } \\
\text { ROMA E COME } \\
\text { ANTICAMENTE } \\
\text { ERONO }
\end{gathered}
$$

The date at the foot of the title page,

\section{ROM $A$}

1490

and the letters SPQR on the escutcheon at the top also seem to have been inserted over an erasure, though on the original part of the title page: while the inscriptions in the medallions on each side at the top have also been removed, and the arms in the centre of the binding have been made unrecognisable.

The date 1490 is apocryphal and probably fictitious, while 1590 (assuming this to have been a mistake) is a little too late for the contents of the book. That the text is fragmentary is further clear from the bigh numbers of some of the chapters into which it is divided -thus in the legend to the view on $\mathrm{f}, 36$ there is a reference to Book II, ch. xviii, and ch. xxxiii deals with the church of S. Lorenzo. This is unfortunate, for some of it is not without interest: and it does not correspond in any way with any of the printed or MS. descriptions of Rome of the time of Gregory XIII., to which it clearly belongs, both from the character of the views, and from 
indications in the text itself, where (on $f .3^{r}$ ) we find Pope Gregory XIII. mentioned as living (1572-1585) : perhaps, indeed, we may fix it more closely to the year 1581 (f, 9 -see below). We may first, perhaps, deal with the scanty remains of the text and then turn to the illustrations.

The text has often been rendered difficult to read by the pages having been gummed together, and part of one leaf having come off on to the one opposite. I must acknowledge the help of Mr. G. McN. Rushforth, who kindly deciphered considerable portions of it for me. Originally it was very clearly written in a neat handanother indication that it was a presentation copy.

On f. $3^{\mathrm{v}}$ we find the beginning of a description of certain notable things at S. Peter's. Inasmuch as it occurs on the back of p. 35 of the original numbering, and is the beginning of ch. $\mathrm{v}$, we must suppose that we have lost the whole of the first book of the text, and the first four chapters of the second, except for the last page of the fourth chapter on p. 2 , which is still gummed on to the title page, and therefore undecipherable except for a few words.

Di alcune cose notabili di S. Pietro.

Cap. v.

Nel Cortile subito entrato a man manca si vede una sepoltura di marmo, ${ }^{1}$ doue sono sepeliti gli Imperatori Ottone II. Honorio, \& Valentiniano II, Augusti ; \& nel mezo del Cortile una capelletta con otto colonne di Porfido, coperta di bronzo, con due Pauoni, et quattro delfini sopra \& una pigna sotto di notabil grandezza pur di metallo, la quale vuole il Pannouino, ${ }^{2}$ che fosse ricettacolo dell'acqua di quella fontana che Papa Adriano primo, \& di poi Simmaco condusse in questo Cortile dal lago Sabbatino per seruitio della Chiesa, e de pellegrini; ma s'inganna, perche ne quella pigna e disposta in maniera, che sia capace di riceuere, o di mandar fuori acqua per alcun seruitio, ne il condotto vi era sotto, ma vn poco piu verso la chiesa, come si e discoperto, et scaturiua l'acqua in un altro vaso di metallo, che il

1 This sarcophagus is shown in the drawing of 'Tasselli, reproduced by Grisar, Analecta Romana $I_{\text {., }}$ t. xi. xii : the latter is probably right (p. 504) in maintaining that the name, though frequently given by earlier writers, is incorrect. The mention of Valentinian II. (correctly III.) is a mere mistake, due, perhaps, to the existence of the two imperial nausolea (S. Petronilla and S. Andrea) on the west side of the church.

2 For the pinecone and its ranopy, cf. the exhaustive article of Hülsen in Rom. Mitt., 1904, 87, sqq. Panvinius' description is contained in his MS. work, De Basilica Vaticana in Cod. Vat., 7010 (published by Mai, Spicilegium, ix, $368 s q q)$. 
nostro Beatissimo Gregorio ha fatto leuare con certi fragmenti di marmo, et metter nella chiesa della Madonna della febre per nettare il Cortile. Vogliono, che questa pigna con le cose intorno fosse nella mole d'Adriano, ma nel rouerso della medaglia di questo Imperatore non si vede questo suo mausoleo, ne si sa per altro; si puo ben credere, che, o di questo, o del cerchio di Nerone ruinato nell' edificatione di S. Pietro, o d'altro edifitio antico fossero quiui da i Papi per ornameto, et per memoria collocati, come usarono di fare in altri luoghi d'altre simili anticaglie raccolte. Sopra le porte della chiesa sono le catene del porto di Smirna, et certe bandiere tolte a Turchi al tempo di Sisto IIII., \& altre della fortezza d'Affrica al tempo di Giulio III., \& nella chiesa quelle de gli Vgunotti, mandate da Carlo IX. Re di Franza alla felice memoria di Pio V. A man destra della porta maggiore sono due tauole di marmo, che contengono la donatione dimolti terreni, \& beni.

The account we have here adds an important detail, which confirms Hülsen's theory that the pinecone (though originally a fountain) did not serve as a fountain in the atrium of the old church of $\mathrm{S}$. Peter, and is decisive evidence against Petersen's contention' ${ }^{1}$ that it is to be identified with the cantharus described by S. Paulinus of Nola in a letter of A.D. 397-the only ground for supposing the migration of the pigna to the Vatican before the middle of the twelfth century A.D. (Hulsen, op. cit., 105). It expressly states that " the water pipe was not under it, but a little further towards the church, as has been discovered, and the water gushed out into another basin of bronze, which our most blessed Gregory has caused to be removed with certain fragments of marble, and placed in the church of the Madonna della Febbre to clear the court." The basin is shown as still in position, though by that time it must have been moved, (No. 117) in the plan of Alfarano (1590) and mentioned by Panvinius, with an "ancient basin of porphyry," which had been placed by Symmachus in platea ante gradus (Duchesne, Lib. Pont., i, 267 ; De Rossi, Inscr. christ., ii, 220, 429).

The description of Grimaldi in Cod. Barb. xxxiv, 50 (now Barb. Lat. 2733), 151 sqq., quoted by Hulsen, op. cit., 95 , is in agreement with the new account:

"Leo III. fecit iuxta ipsam pineam alium fontem ad bibendum commodiorem, cuius magnum labrum aeneum rotundum conversum est in sacros usus basilicae sub Gregorio XIII., apparebatque ante 
atrii demolitionem locus ipsius fontis Leoniani et fistulae ducentis aquam habentis unius papalis Julii formam."

The size of the Julius of the period (1606-15) was 1.05 inches or $27 \mathrm{~mm}$.

The church of S. Maria della Febbre was the eastern one of the two circular mausolea which stood close to S. Peter's on the south, known also as S. Andrea, and destroyed by Pius VI.

The fate of the bronze basin is uncertain ${ }^{1}$ : it is not among the objects mentioned by the chirografo of 1613 . in the Archivio di Stato (published by Gori in Arch. Stor. Artistico, iv (1881) 230), as used for the statue of the Virgin on the column in front of S. Maria Maggiore. This document mentions the melting down of

"quattro ferrate, ciascheduna di tre pezzi con alcuni archi" similmente di metallo, gia posti intorno alla pigna, che stava avanti all' atrio della vecchia basilica di S. Pietro":

Lanciani, Pagan and Christian Rome, 136 ${ }^{2}$, infers. that the four dolphins and the two of the four peacocks which no longer exist (two, as is well known, are still, with the pinecone itself, in the Giardino della Pigna). disappeared on the same occasion.

The inference is very likely correct, and the account given by our author is no obstacle to it. For the other two peacocks, according to the drawing in an eleventh century MS. from the abbey of Farfa, now in the Eton College Library (No. 124), stood, not on the canopy, but at each extremity of the gable of S. Peter's itself, Grisar, op. cit. $473 s q q$. maintains successfully that this. cannot be a mere invention of the artist, but must have some foundation in fact. And the number four suits far better the theory that their original position was, as a passage in the Mirabilia tells us, the mausoleum of Hadrian, whether we suppose that they stood at the angles of the bronze railing which enclosed the whole, as Hülsen thinks (in Jordan, Topographie, i, 3, 665), or

1 De Rossi (op. cit., 429), in the absence of other indications, seems to attach little importance (id quod unde didicerit, nescio) to what Grimaldi says about the bronze basin.

2 "In 1613 the semicircular pediments, the four dolphins, tro of the peacocks and the dome were melted to provide the ten thousand pounds of metal required for the casting of the statue," etc. 
on the four pillars of the triple entrance to the enclosure as Petersen supposes (in Amelung, Die Skulpturen des Vatikanischen Museums, i, p. 895). A good photograph of this entrance is given in Borsari's account of the excavations of 1892 (Not. Scav., 1892, 422, fig. 8).

From the absence of any mention of the bronze basin in any later accounts ( $I$ have searched several of the seventeenth century guide books of Rome) and Grimaldi's phrase that the bronze basin had been converted "to sacred uses" by Gregory XIII. (which seems to mean that in his day it was no longer in existence), I think we may infer that it only remained a short time in S. Maria della Febbre, and was soon melted down.

On f. 4 is the conclusion of ch. $v$ of the text (how much has fallen out, it is impossible to say-probably two pages at least) and the commencement of ch. vi. The page bears the number 41 , and the text is as follows :

tale degli ammorbati con pienissima indulgenza, che sono dicenoue chiese in tutte, et tre ospitali. Il giorno della statione in ciascheduna di esse, e il giorno della sua festa; saluo, che di S. Angelo, che dura per tutta l'Ottaua.

De penitentieri et della dignita

di questa Chiesa. Cap. vi.

Sono con bellissimo ordine disposti in questa Chiesa, come ancora D) nell' altre principali molti Confessori di varie nationi addimandati penitentieri con potesta d' assolvere di tutti peccati; et accioche concorrendo ivi le genti da tutte le parti del Mondo; ognuno possa confessandosi esser inteso ; hoggidi per ordine di Pio V. vi stanno preti de la compagnia del buon Gesù. Questi penitentieri cancellano i peccati veniali toccando le persone con quella bachetta che tengono in mano. Questa chiesa ancorche per la prerogativa della dignita episcopale sia minor di S. Giovanni Laterano ; nondimeno per la gran quantita di corpi santi e di altre reliquie e per la residenza papale, \& per essersi fatte in essa sempre mai quelle maggiori ceremonie et attioni che soglia fare il Papa trattando con Regi \& Imperatori nelle creationi coronationi abiurationi giuramenti di fedelta et gli luoghi d'ubidienza et per il concorso della Corte et de i pellegrini di tutte le 'parti in tutti i tempi et specialmente nell' anno del Giubileo quiui principalmente fondato da Bonifatio et la più famosa dell' uniuerso e vi si aggiungera la stupenda sua Fabrica incominciata da Giulio II. sebbene con altro modello la quale ridotta nel modo ch'hoggidi si vede e di Michelangelo Buonaroti; mi e parso con la sequente figura dimostrare qual'ella sara quando sara finita, essendo fabrica digna 

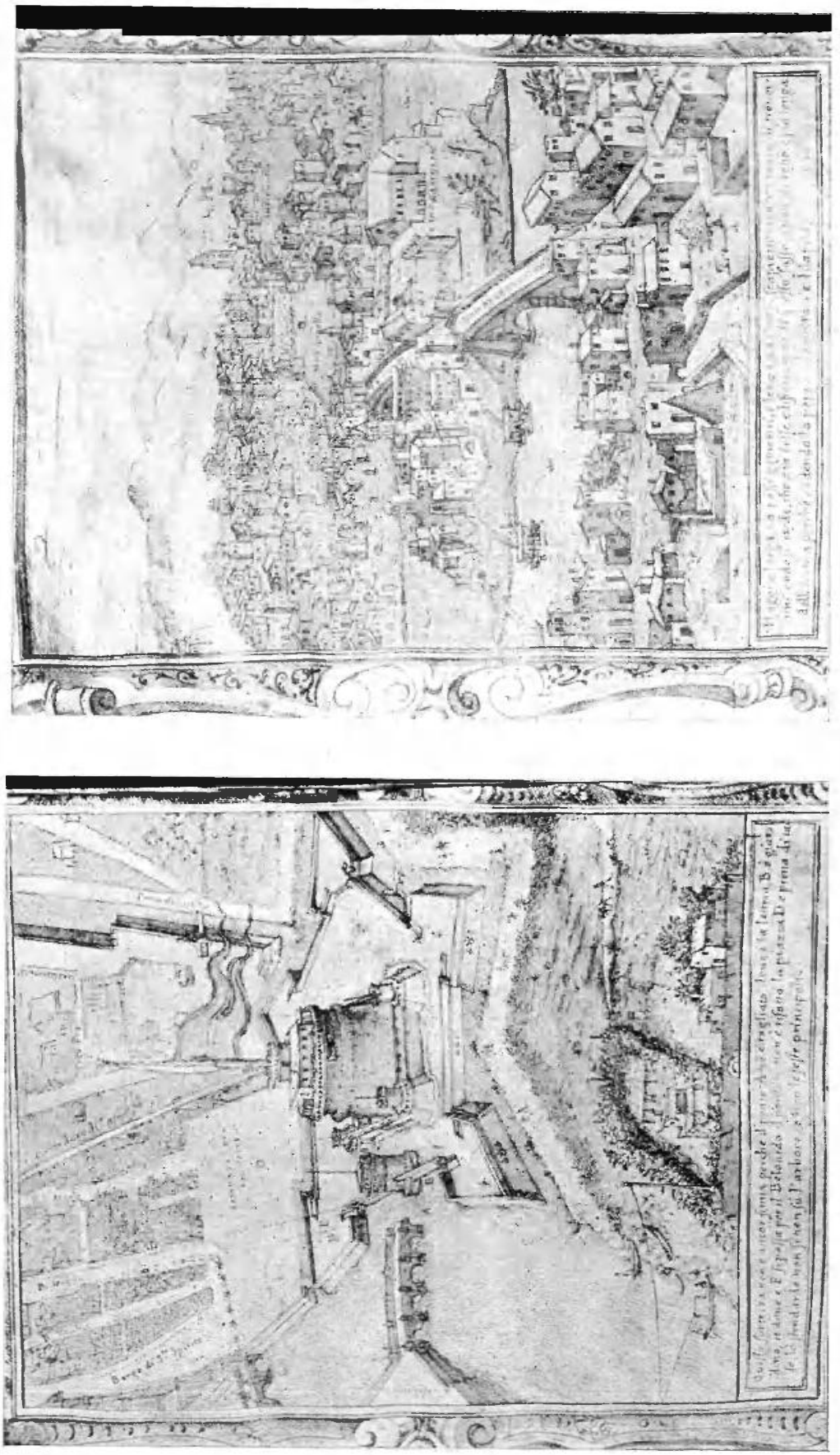
d'essere veduta $\mathrm{p}(\mathrm{er})$ che pareggia gli antichi et supera i moderni a tutti paesi. (The view of S. Peter's referred to is on the following page, $4^{v}$.)

On $\mathrm{f} .6^{\mathrm{v}}$ is the termination of the description of Castel S. Angelo, which occupied ch. ix. (containing a reference to the view of the Castello on f. 6), and the commencement of that of Trastevere, which occupied ch. $x$. The conclusion of ch. $x$ is to be found on $f$, 7 , which bears the earlier number 49. It does not seem to present any points of especial interest, and is therefore not given in extenso; the two passages already reproduced may eventually serve for the identification of the author of the treatise.

The next fragment of text is to be found on $f 8^{v}$ and $9^{\mathrm{r}}$. It begins with a description of the Tiber island (ch. xvi), and the legend of its formation from the throwing into the river of the corncrop from the field of the Tarquins, and turns to describe the church of $S$. Bartolommeo. The only point of interest is the concluding paragraph which speaks of

"la chiesa di S. Giouanni Collauita, gia monasterio di monache, al presente trasportate da Papa Gregorio nel monasterio di Sant' Anna hauendo concesso la chiesa a Gesuiti. Oltra queste due chiese ui sono alcune habitationi di particolari, come si e ueduto nella figura moderna."

The exact dates of the transference of the Benedictine nuns from the church of $\mathrm{S}$. Giovanni Calibita to $\mathrm{S}$. Anna dei Funari ${ }^{1}$ and of its concession, not as a matter of fact to the Jesuits, but to the Frati di S. Giovanni de Dio, are naturally of importance for the dating of the text. The first edition of the Cose Meravigliose dell' Alma Citta di Roma (1568), p. 11, ${ }^{\vee 2}$ speaks of the nuns as still there, and so, but wrongly, does that of 1575 , while Cancellieri, Notizie Istoriche delle Chiese di S. Maria in Iulia, etc. (Bologna, 1823), gives this accurately. He quotes a document from the archives of S. Anna dei Funari (p. 4), according to which on November 23, 1573, Gregory XIII. ordered the transference of the nuns, on account of the convent being

1 The church was demolished in 1887 to make room for the Via Arenula (Lanciani, Golden Days of the Renaissance, 223 sqq.).
2 This work is interesting as providing an itinerary for seeing the whole of Rome in three days (pp. $\left.38^{v}-45^{v}\right)$. 
so subject to inundations, of which there had been one in the previous year (Bonini, Tevere Incatenato, 63).

Gregorius Papa XIII., propter crebras Tiberis inundationes, et nurorum corrosiones, Monasterium S. Mariae, alias S. Joannis Calocitae, sive de Licaonia in Insula Urbis, suppressa Abbatissa, Moniales transferri iussit ad Monasterium S.M. in Julia, alias S. Annae, cui univit bona et jura.

In 1575 a pilgrimage from Bologna came to Rome for the Jubilee, and some of the pilgrims, with other Bolognese already domiciled in Rome, bought the church and the nunnery on June 2 of that year (p. 8), and the Pope, by a bull of March 27, 1576, confirmed the verbal approval of the confraternity which they had formed, which he had given on September 24 of the preceding year (p. 110).

In 1581, however, the confraternity removed to the church of S. Tommaso della Catena or degli Spagnuoli, close to the Palazzo Farnese, the parish which had hitherto belonged to this church being incorporated with that of S. Salvatore in Campo, by a bull of June 13, 1581 (p. 116), while the church of S. Giovanni Calibita was transferred in the same year to the monks of the order of S. Giovanni di Dio, or Fatebenefratelli (pp. 15 sqq.)

Panciroli, in the first edition of his Tesori Nascosti (1600), pp. 213, 370, mentions the transference of the nuns, and the coming of the Frati di S. Giovanni di Dio, or Fatebenefratelli (who are still there), but does not give the date: ${ }^{1}$ he adds it, however, in the second edition (1625), p. 626, and there states it as 1581 .

The point is of importance, as it gives a terminus post quem for the compilation of the text.

Armellini, Chiese di Roma (ed. 2, 618), quotes the Stato temporale delle chiese di Roma (Arch. Vat., tom. ii, p. 120 , under the year 1662) which gives the date of the foundation of the church as 1584. This is, however, a somewhat later authority, and appears to have quite confused the issue, inasmuch as it attributes the foundation and construction of the church to the Compagnia dei Bolognesi. We may therefore consider 1581 to be the date of the concession of the church to the Fatebenefratelli.

1 Nibbr, Roma Moderna, i, 99, wrongly gires the date as 1297. 
Cancellieri (pp. 10, ${ }^{1} 17$ ) seems to assume from the inscription of 1640, given by Martinelli (Roma ex Ethrica Sacra, 124), which records the restoration of the church in that year, that they did not occupy the church until then, so that Panciroli is wrong in saying (Tesori Nascosti (1625), p. 627) that they restored the church about the year 1600 , and that it was then and not before that the relics of various martyrs were found. But this criticism seems out of place. Panciroli must have known of a restoration which occurred in his own time; and the bull of 1575 only refers to the bodies of the martyrs as reposing in the church, to which effect there was probably a tradition long enough before the actual discovery of the stone which Panciroli records.

After ch. xvi, which we thus have entire, begins ch. xvii, "Del velabro e del Pallatino verso Ponente," which contains an account of no great interest, and which continues on $\mathrm{f} \cdot 10^{\mathrm{v}}$ (the original $52^{\mathrm{v}}$ ). The original p. 53 is missing, so that p. $11^{\mathrm{r}}$, bearing the number 54 of the previous pagination, does not continue what precedes, but begins to deal with the Aventine. Here we have a mention of the "arch built in honour of Horatius Cocles of most beautiful marbles, destroyed in the time of Eugenius IV. to make lime of them."

The reference is to the arch of P. Lentulus Scipio and T. Quinctius Crispinus Valerianus, erected in A.D. 2, and destroyed just in the time of this Pope (Flavius Blondus, Roma instaurata, i, 20).

"vetustissimos arcus marmoreos ut in calcem decoquerentur dolentes vidimus a fundamentis excidi. Quos arcus fama fuit et quibusdam indicantibus litteris apparebat Horatii Coclitis honori fuisse a maioribus excitatos."

The account of the Aventine continues on $\mathrm{f} .13^{\mathrm{v}}$ (the earlier $56^{v}$ ), the churches of S. Sabina and S. Alessio being described. In the former our author notes the existence of an ancient weight of Lucullan marble, built in close

${ }^{1}$ p. 10: "prese dunque un doppio abbaglio il Panciroli, arendo scritto che questa chiesa fu rinnovata circa l'Anno Santo 1600 , quando lo fu quaras t' anni dopo: e che in quell' occasione fu scoperta l'Arca marmorea, in cui erano incisi i nomi de' quattro SS. MMI. giacche ciò dev'essere accaduto molto prima, facendosene menzione nella Bolla di Gregorio XIII. fin dal 1575."

p. 17: "Nel Bollario di Sisto V. si legge, che fu tenuto il primo Capitolo Generale in questo luogo ... pertanto i PP. Fatebenefratelli non vi poterono subentrare, che posteriormente." 
to the high altar, said to have been thrown at S. Dominic by the devil as he prayed. This is mentioned by Panciroli (1625), 640. On f. 14 comes a chapter (no. xxxiii) on the church of S. Lorenzo fuori le Mura. 'The high number-for that dealing with the Aventine can hardly have been more than about $\mathrm{xix}^{1}$ - shows that here there is a considerable lacuna in the text.

We may now proceed to the consideration of the drawings. As we have seen, they fall into two classesthe actual and the restored views, the views of ancient Rome as the Renaissance antiquaries saw it actually before them and the reconstructions of what they imagined it to have been, and are generally arranged in pairs, the restoration coming first in order. The other class, however, being a good deal the more important, must be considered first. The first of these is a view of S. Peter's (f, $4^{\mathrm{v}}$ ) as it was intended to be when completed according to Michaelangelo's design, in the form of a Greek cross. We come next (f. 5) to a view of the Teatro di Belvedere, which is very like that given in a well-known engraving, representing the Giostra of 1565, of the Speculum Urbis Romae (Quaritch, no. 354; of. Papers of the British School at Rome, ii, p. 83), by Du Perac, engraved by Lafieri.

It is not, however, a mere copy from it : the cruciform arbour with a dome in the centre-so common in the sixteenth century gardens in Rome-is here far less prominent, and we have, too, part of the bastion of Paul III. indicated below the Belvedere on the right. The great change in the appearance of the court came with the erection of the library by Sixtus V., which divided it into two. On the other hand, it was already in the time of Paul III. that part of Bramante's original structure had collapsed (Papers, cit. p. 31, cf. pl. 43, 45), rendering it necessary to strengthen it largely with brickwork, and so obscuring almost entirely Bramante's original plan, the effect of which would have been immeasurably finer than it is at present. Next comes (f. 6 ) a view of the Castle of S. Angelo, showing the fortifications of Pius IV. already in existence. It is very similar to Dosio's view,

1 That ch. xviii dealt with the Pyramid of Cestius we have already seen (supra, 246). 


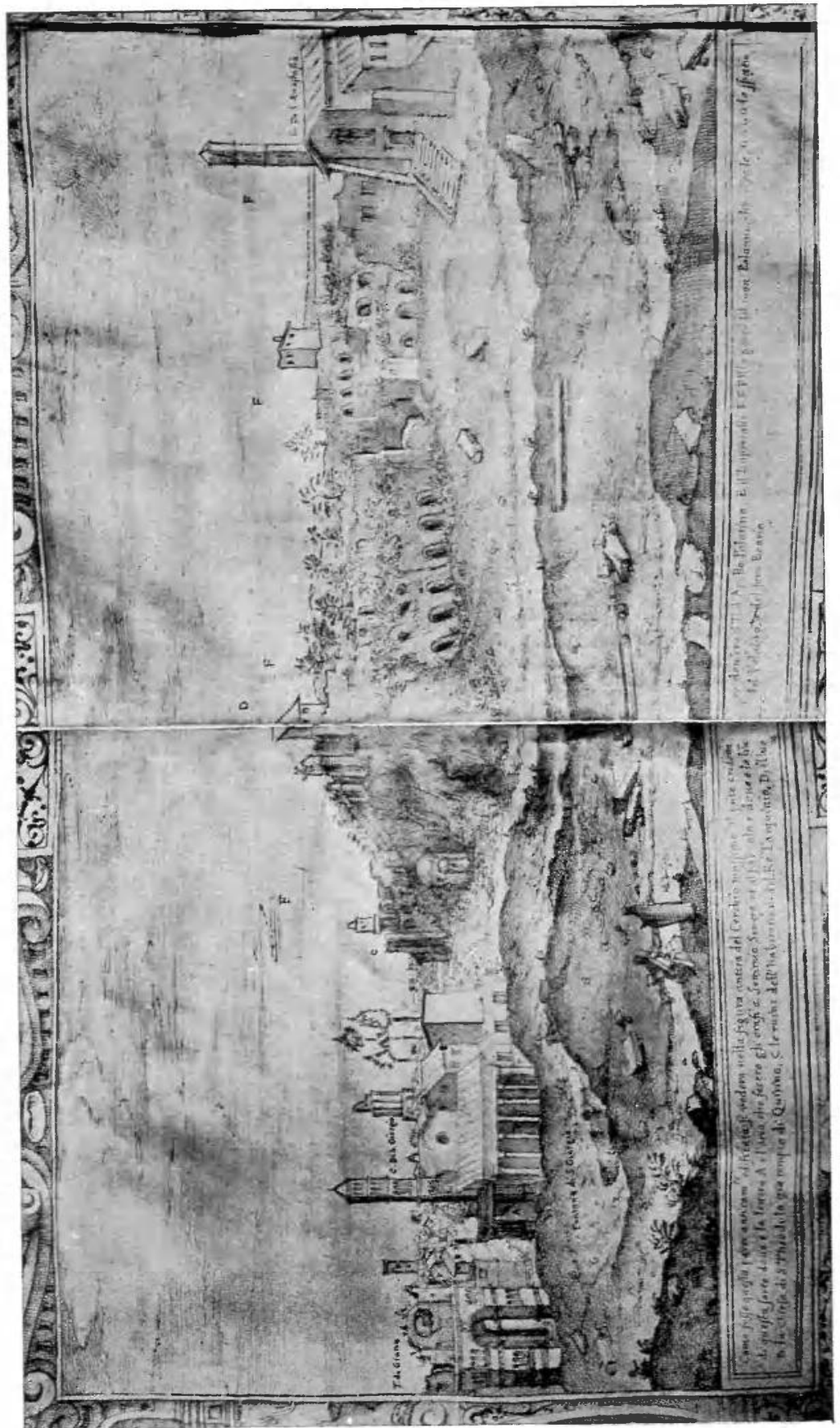

足 
Urbis Romae Aedificiorum Illustrium quae supersunt reliquiae (1569), pl. 48, but differs in important details. (Plate I, fig. 1.)

There appears to have been in the time of Gregory XIII. a project for cutting the last arch on the right bank of the Ponte S. Angelo, so reducing it to purely military uses, and restoring the old Pons Triumphalis for traffic, after having enlarged the Piazza in front of the castle and demolished a good part of the hospital of S. Spirito. This is explained in the text to our view :

"Questa fortezza non e ancor finita, perche il ponte $A$ no e tagliato, doue e la lettera $\mathrm{B}$ è giardino, et doue e $\mathrm{E}$ si passa per il Beloardo, il ponte non e rifatto, la piazza $\mathrm{D}$ e piena di case, lo stendardo non si tien su' l'arbore se non le feste principali."

The garden is shown in the engravings in the Speculum Urbis Romae just east of the round tower of Alexander VI. (Borgatti, Castel S. Angelo, tav. xvii, fig. 29), destroyed by Urban VIII. Of this project, which was not carried into execution, I know nothing from any other source of information, except that the restoration of the Pons Triumphalis was projected by Julius II. in connexion with the laying out of the Via Giulia, "quem quidem tua Beatitudo vult restituere et iam a populo Romano pons Iulii vocatur." (Albertini, Opusculum de mirclitibus novae et veteris Urbis Romae, $12^{\mathrm{v}}, 95^{\mathrm{v}}$ of the original edition and of that of 1515 ; p. $v$, lxxiiii of the reprint of Mazochi (1523).) But it will be news to some of my readers that the east wing of the hospital of $\mathrm{S}$. Spirito was almost sacrificed for a scheme for a new bridge over three hundred years ago. It is perhaps too much to hope that the hospital may survive untouched the scheme for the Ponte Vittorio Emanuele, though the wing which will now be demolished was only added by Benedict XIV.

The next view (Plate I, fig. 2) depicts the Island of the Tiber, with the churches of S. Bartolommeo and S. Giovanni Calibita, the former before its "restoration" and modernization by Martino Longhi the younger in 1625 , when we see that the latter too had a pointed and arcaded campanile. On the further bank we see much of the rest of Rome, in which nothing seems to require particular comment, and may note the fortified palace of 
the Savelli on the ruins of the theatre of Marcellus (cf. Egger, Codex Escurialensis, Textband, Pl. V (= Tafeln f. $56^{v}$ ) and p. 140, fig. 61 (from Antonio Tempesta's birdseye view of 1593).

The next (f. $9^{\mathrm{r}}, 10^{\prime}$ ) is a double view, ranging from the arch of Janus Quadrifrons to the church of $\mathrm{S}$. Anastasia. (Plate II.) The left-hand portion closely resembles Duperac's Vestigi dell' Antichitd di Roma (1575), Pl. 12. Some of the drawings, indeed, of which I have not thought it worth while to give reproductions, are absolute copies from this work.

For S. Anastasia compare the drawing from the Stuttgart sketch book (early sixteenth century) reproduced by Grisar, Analecta Romana, i, 605. The modernization of the church, in which its original form has been entirely obliterated, dates from 1636. "The ruins of the habitations of King Tarquin" are simply the Temple of Augustus. The temple of Apollo is of course quite wrongly placed.

The next (f. $12^{\mathrm{v}}, 13$, Plate III) is a view of the Marmorata and the Aventine, with the various ancient substructions on its slopes, of which a good deal still remains. The right half is identical with Duperac, op. cit. 33, but the left half differs slightly. The column seen in the foreground with the legend "la colona del Antoniana donata al gran duca" in a ship was removed from the tepidarium of the baths of Caracalla in 1564 to Florence, set up in the piazza di S. Triniti, and crowned with a bronze statue of Justice (Lanciani, Ruins and Excavations, 539, and Storia degli Scavi, iii, 114).

F. 15 gives a view of the Capitol, according to the plans of Michelangelo, with the palaces on each side shown (of course fictitiously as regards the present Museo Capitolino)' as complete, but the old battlemented tower still crowning the Palazzo del Senatore. This battlemented tower occurs in other views also in this work. Its construction was begun in 1578, and pursued until 1580, when money became short (Rodocanachi, Le Capitole Romain, 90), but it seems to have been completed soon after that year, if not during it : in any case before

1 This is also the case in the riews of the Capitol in the Sprculum Urbis Romae (Quaritch, No. 15) and the rare 


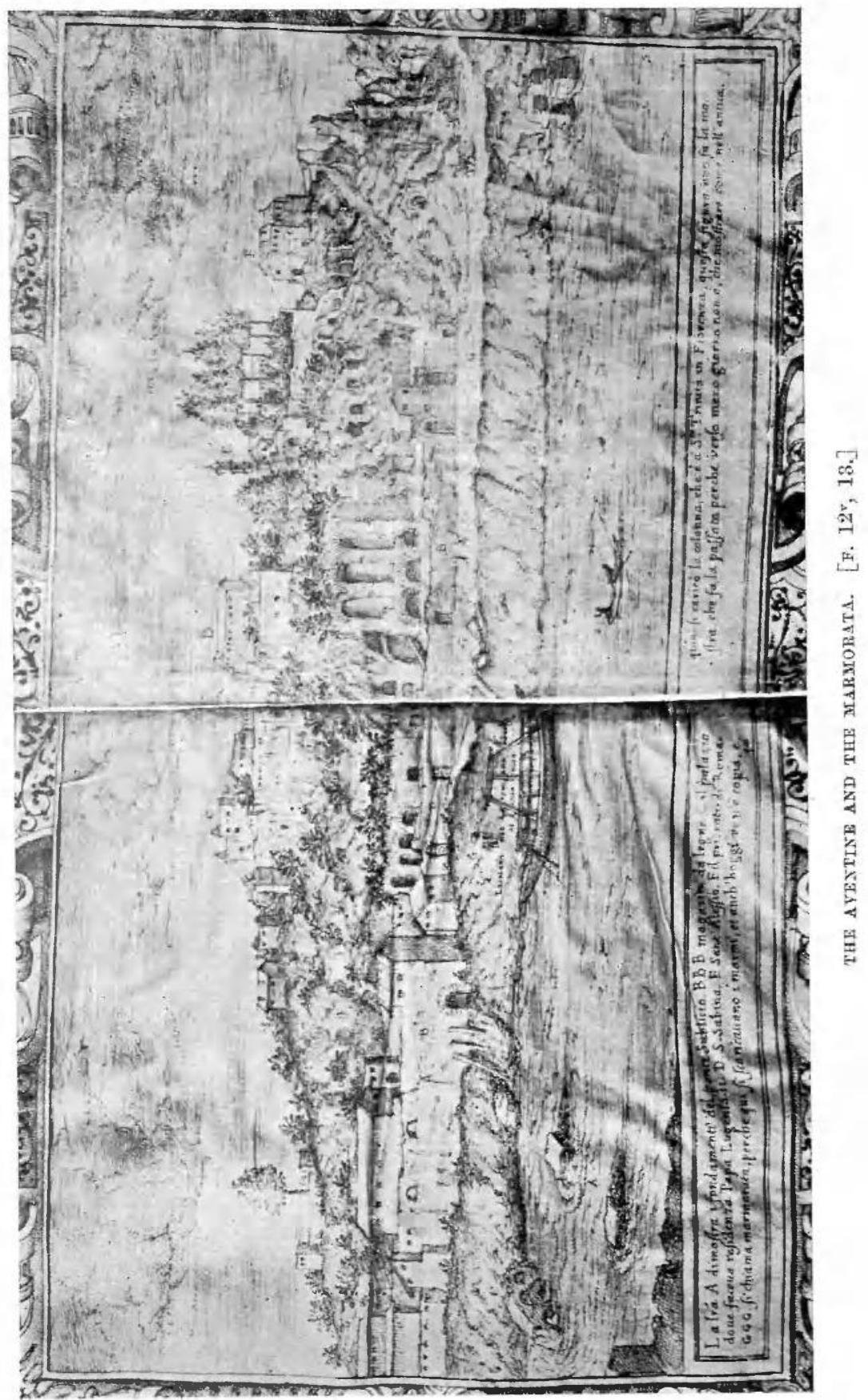


the end of the reign of Gregory XIII., whose name is inscribed upon the cornice at its summit.

The next view (ff. 16 -17 ) (Plate IV) shows the Forum Romanum looking up towards the Capitol, which, though it presents no features of especial interest, is a good view of the period, and independent, as far as I know, of any other work. For the tower on the arch of Septimius Severus cf. Melanges de l'École Française, 1906, 185. In the view before us there is no tower on the gable of the Curia, but the usual Campanile on the south-east side (ibid.).

The Forum of Nerva $\left(18^{v}, 19\right)$ is to all intents and purposes the same view as that of Duperac, Vestigii, tav. vi. The view shows the temple of Minerva, destroyed in 1605, the Church of S. Quirico, the so-called Arco di Noe and the Colonnacce. A still earlier view of the same ruins may be cited-the so-called Asinaria. A copy of the first edition of this rare print of 1553 is preserved in the Gabinetto delle Stampe of the Galleria Corsini ; $c f$. Hermanin, Catalogo delle incisioni con vedute romane, p. xlvii, no. 4. It bears the date 1553, and the legend "M.L. cum priuilegio" (no doubt Michele Lucchese), i.e., Michele Crechi of Lucca : $c f$. Nagler, Monogrammisten, iv, p. 623 .

There was a re-issue of it in 1564, a copy of which, in the British Museum, is described by Cumberland, Critical Catalogue of Rare and Valuable Italian Prints, p. 524 no. 61. In this (I describe it from a copy in my own collection) the legends have been altered. That on the right-hand tablet has been re-engraved, though the wording of the first portion is identical; but the couplet,

"Chi predica al deserto perde la fatica el Sermone, Et chi laua el capo al Asino perde la lescia el Sapone,"

has been added.

The tablet above in the centre, too, is different in the original plate, being there smaller, and having only the Latin legend. Further, the legends in the middle of the picture have been added. The satire is conjectured by Hermanin to have some literary bearing: it is indeed obviously directed against some persons who objected to scientific and literary pursuits, though it would seem that 
in the time of Julius III. this would have had far less point than in 1564, directly after the meeting of the Council of Trent.

On f. 20 is a view of the Basilica of Constantine, which seems to be closely similar to Duperac, Vestigii, tav. 5 : the large heap of fallen fragments of the roof is noticeable, and (as in other views of the period) we may see to what height the debris had accumulated in the interior by remarking that no trace is to be seen of the pillars which supported the south-west aisle. The last column, still seen in this drawing, was removed by Paul $V$. in 1613 , and set up in front of S. Maria Maggiore.

On f. $21^{v}, 22$ is a view (Plate V) of the south side of the Palatine and the valley of the Circus Maximus, again closely similar to Duperac, op. cit., 11 : while the views of the Septizonium (f. 23) ; of the Colosseum (f. 24); of the "trofei di Mario" (f. 25) ; of the Column of M. Aurelius (f. 27$)$; of the Baths of Caracalla $\left(29^{v}, 30\right)$; of the Baths of Diocletian (f $31^{v}, 32$ ) ; of the Pantheon (f. 33) ; and of the Amphitheatrum Castrense (f. 34), are all practically identical with the plates in this work, though the legends at the foot are slightly different. We get, however, the same name, "Scuola di Virgilio," for the Septizonium. The view of the Forum of Trajan (f. 26) (Plate VI, fig. 1) on the other hand, though it bears a very close resemblance to Duperac, op. cit., 33, and is probably taken from it, shows a regular wall, with niches, surrounding the excavation in which the column of Trajan stands, whereas in Duperac's view it is simply a cutting in the earth. The date $^{1}$ is fixed as before 1580 , by the fact that the church of S. Maria di Loreto has not as yet its baroque lantern, which was added in that year by Giacomo del Duca. Panciroli, Tesori Nascosti (1625), 295, tells us that it was completed in that year by means of a legacy of 9,000 scudi for the purpose. A view of it with the lantern already upon it will be found in Le Cose meravigliose dell' alma citta di Roma (Francino, 1588), p. 32v.

The view of the Temple of Neptune, on the other hand (f, 28), is taken partly from the view of Dosio, Urbis Romae aedificiorum illustrium quae supersunt

1 This is the date of the origin of the view; but we have already seen (supra,

252 ) that the text can be more exactly dated to 1581 . 


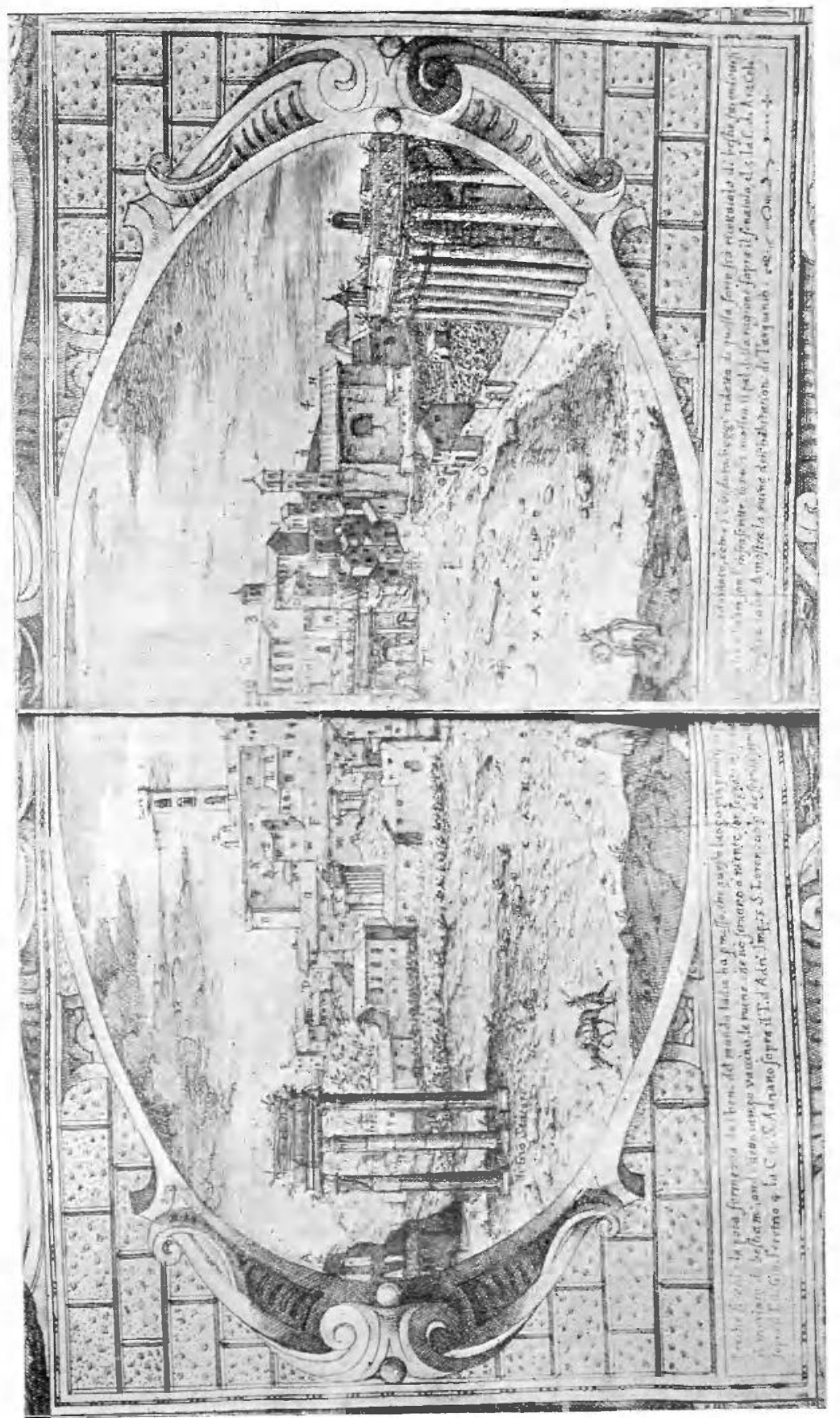




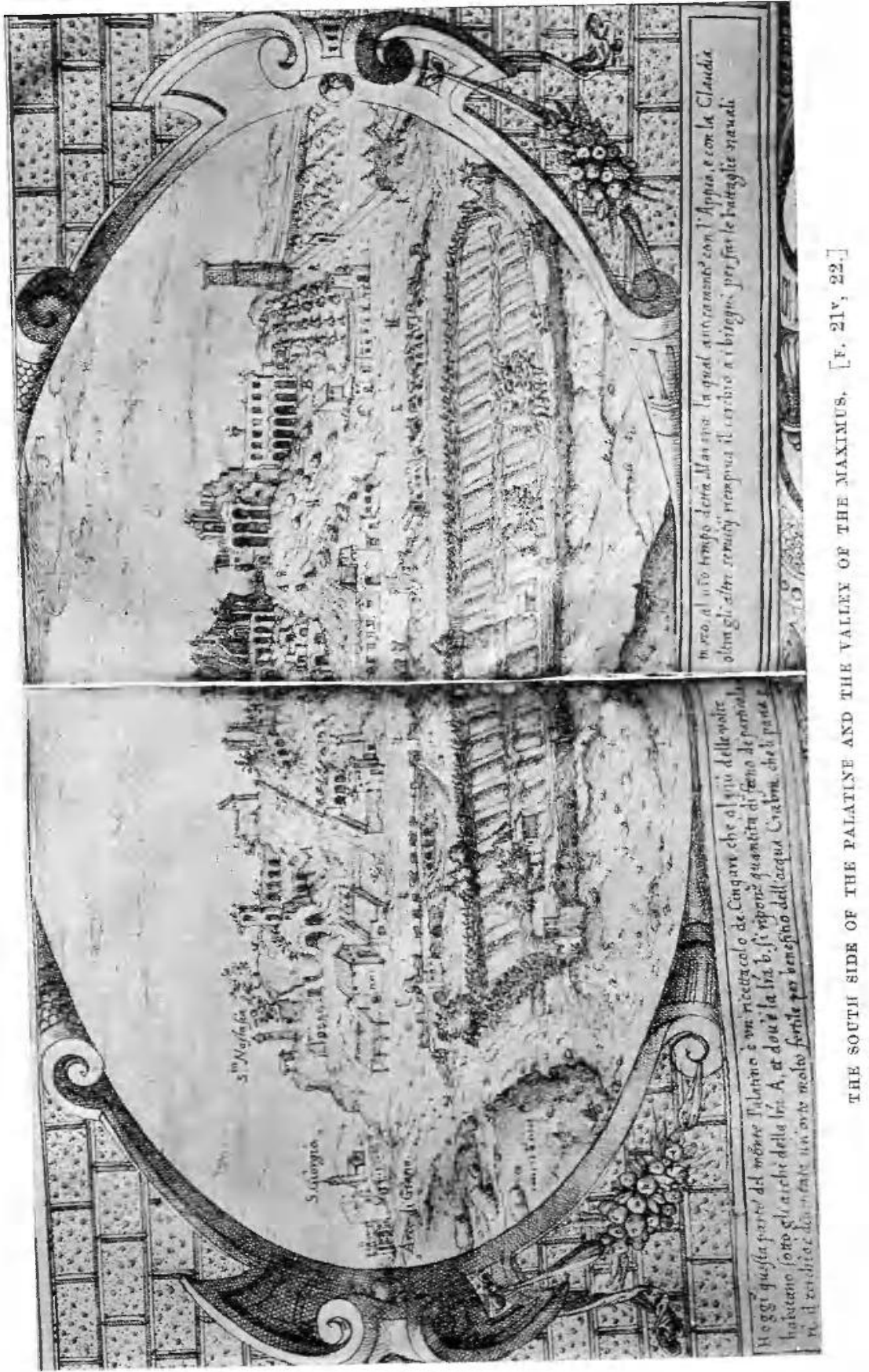


reliquiae, 17, and Duperac, op. cit. 34 (right half). Of the details which occur in the former and not in the latter we may notice the small house in front of the fourth and fifth columns (counting from the left hand): the drawing betrays, however, some independent observation. With regard to the view of the Baths of Diocletian (f. $31^{\nabla}, 32$ ), we may notice that the church of $\mathrm{S}$. Maria degli Angeli is spoken of as still in course of construction-probably in imitation of the legend of Duperac, "Hoggidi ui si fabrica il monasterio delli monaci della certosa." The church, as a fact, was finished on June 5, 1566 (Lanciani, Storia degli Scavi, ii, 137).

An exception to the general rule is formed by the view of the theatre of Marcellus, which bears distinct marks of having been taken from Dosio, op. cit., 31, and not from Duperac; and by that of the statues of Castor and Pollux on the Quirinal, which is taken from a plate in the Speculum Urbis Romae of Lafreri, published in 1564 ( $c f$. Michaelis in Romische Mitteilungen, 1898, 259 sqq.).

We may now turn to the restored drawings. Some of them are derived from sources which I have not yet been able accurately to fix, notably the restoration (f. $15^{\mathrm{v}}, 16$, Plate VII) of the Forum looking towards the Capitol (all the three important restored plans, or rather birdseye views, of ancient Rome of the latter half of the sixteenth century, to which I shall presently allude, take it from a different point of view, inasmuch as they have the west at the bottom, being taken from the Janiculum, the favourite point for sixteenth century plans and views), of the Forum Transitorium (f. 17 $17^{\nabla}, 18$ ) and the Basilica of Constantine $\left(19^{v}\right)$ (Plate VI, fig. 2), which again does not agree with the reconstruction given in any one of the three birdseye views of Rome as conjecturally restored which are mentioned below.

Others of them, of which I give no illustrations (f $2^{\mathrm{r}}$, $3 ; 7^{\mathrm{v}} ; 20^{\mathrm{v}}, 2 \mathrm{~J} ; 24^{\mathrm{v}}$ (these last two indirectly), $25^{\mathrm{r}} ; 26^{\mathrm{v}}$; $\left.28^{\mathrm{v}}, 29 ; 33^{\mathrm{v}} ; 35^{\mathrm{v}}\right)$, are taken directly from the large Urbis Romae Sciographia, a birdseye view of ancient Rome as restored in eight sheets by Duperac, published in April, 1574, ${ }^{1}$ and dedicated to Charles IX. of France.

1 In the previous year he published a much smaller reconstruction, showing only the buildings of which remains

could actually be seen in the Speculum Urbis Romae of Lafreri (Quaritch). 
In the dedication Duperac expressly mentions the use he had made of the fragments of the Forma Urbis, which he was permitted to copy by Card. Alessandro Farnese. His drawings, however, do not, unluckily, exist. The total size is 156 by 104 centimetres. The plates, engraved by Francesco Villamena, are still preserved at the Regia Calcografia at Rome (no. 1439). This plan (I adopt the name "plan" for brevity's sake) is much better than the large restored plan of Rome in twelve sheets by Pirro Ligorio, ${ }^{1}$ which was published in 1561, without knowledge of the fragments of the Forma Urbis (which had not come to light in time for his use), and which, besides, contains many of the false denominations for ancient sites which he himself had invented.

A later plan still is that of Mario Cartaro, published in 1579, a unique copy of which exists in the British Museum, from which is taken the reproduction (on a smaller scale) of Plate XXIII in Rocchi's Piante di Roma del Secolo XVI. Of neither of these last two plans (though he must have known them both) did our author avail himself. It is interesting to notice that the authors of all three plans produced, either as a foundation for, or a complement to their theoretical reconstructions, a plan of the city as it was in their own day.

Pirro Ligorio in 1552 published his Urbis Romae situs cum iis quae adhuc conspiciuntur veter. monument. reliquiis Pyrrho Ligorio Neap. Invent. Romae MDLII. Cum priuilegio sumi Pont. et Senat. Venet. Michaelis Tramezini Formis.

It is a somewhat schematic plan, the ancient buildings being shown in many cases as restored, while the buildings of the modern city are not indicated with any great care, and rather as a setting for the ancient. Nor does

1 Effigies antiquae Romae ex vestigiis aedificiorum ruinis testimonio veterum auctorum, fide numismatum monumentis aeneis plumbaeis saxeis tiglinisque [sic] collecta atque in hane tabellam redacta atque descripta a Pyrrho Ligorio Romano Pioque IIII Pont Max dicata excuderunt Romae Michael et Franciscus Tramezini MDLXI. Cum priuilegio sumi Pont. \& Senat. Venet. Iacobus Bossius Belga, incidebat.
The plates afterwards passed into the hands of "Gio Batista de Rossi in Piazza Nauona," and still later copies bear the imprint "presso Giovanni Scudellari." The plates (eren if not still extant) cannot long have disappeared, inasmuch as the copies of Scudellari are printed upon comparatively modern paper. 


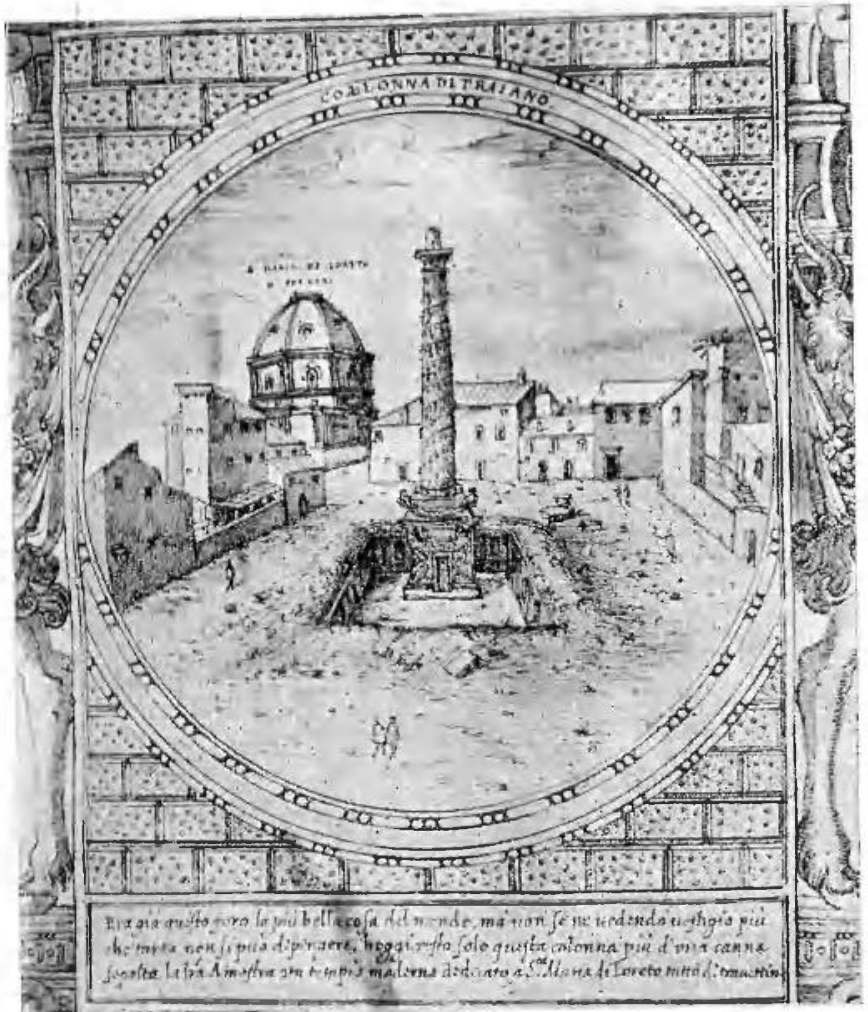

FIG. 1.-THE FORUM OF TRAJAN. [F. 26.] 


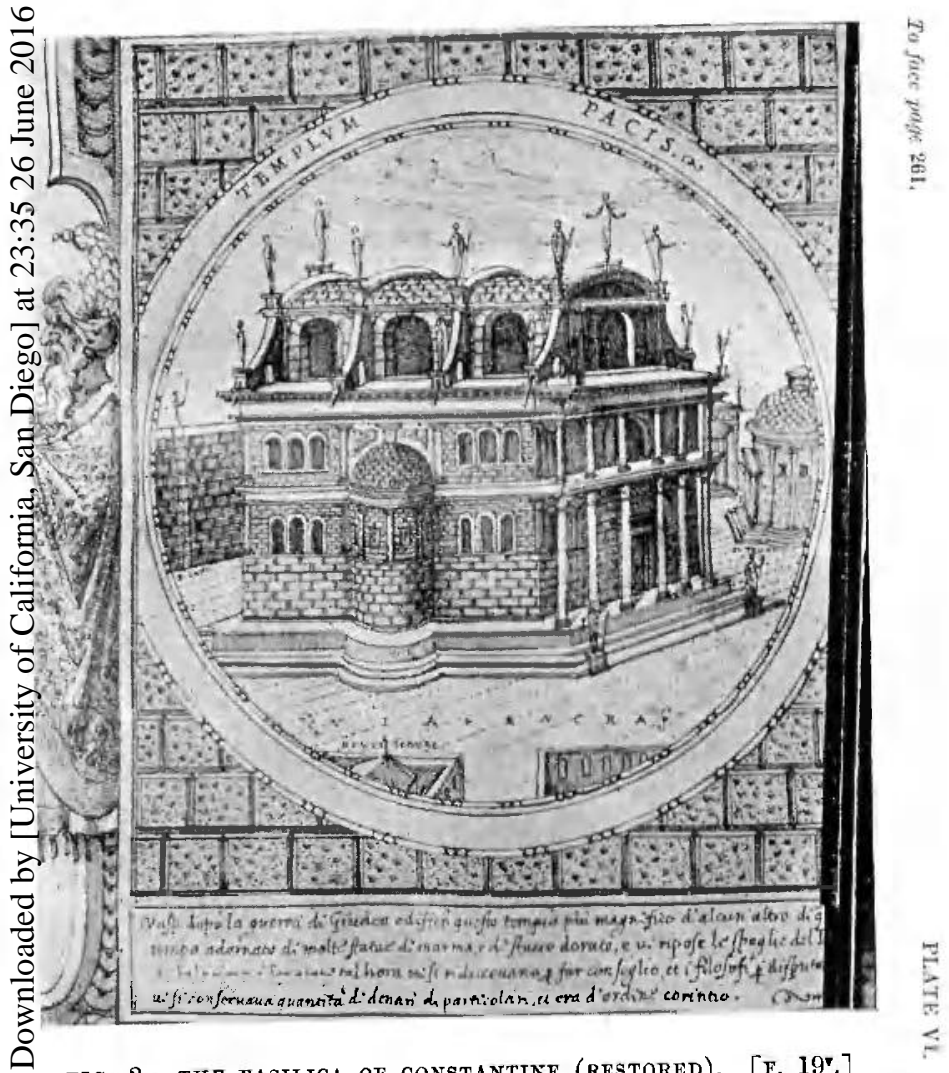

Fig. 2.- TIE Basilica of CONstantine (Bestored). [F. 19.] 
it seem to have ever been published on a large scale, corresponding with that of his restored plan.

The plans of contemporary Rome of the other two artists are works of a higher calibre, but of surprising rarity. That of Duperac, in four sheets, was published by Antoine Lafreri three years after his large Sciographia under the title Nova Urbis Romae Descriptio and dedicated to Henry III. of France on December 1, 1577 . I shall only speak briefly of it, as a copy of it was discovered in the British Museum by Father F. Ehrle several years ago, and will shortly be published by him. He regards it as the best plan of Rome of the latter half of the sixteenth century. A year and a half back a re-edition of this plan, dated 1640 , came into my collection ; from internal evidence it was obvious that it belonged to the time of Gregory XIII., and Father Ehrle, on hearing of it, suspected what it must be. The dedication has been changed by Giambattista de Rossi, into whose hands it had fallen, and the plan brought up to date in the main, but only to a certain extent.

Thus we find that the Palazzo Rospigliosi, built in 1603, has not been inserted, though the Palazzo Barberini has, and that the Temple of Minerva, in the Forum of Nerva, though destroyed in 1605, is still shown. In this connection it is worth noting that here we have a representation (the most distinct one known to me) of the arch which formed the south-west entrance to the Forum of Nerva. This is shown in the plans by Antonio da Sangallo the younger (Uffizi, 896) and Baldassare Peruzzi (Uffizi, 625) published by Lanciani in his article on L'Aula e gli Uffici del Senato Romano (from Mem. Lincei, 1882, Pl. I, II, cf. p. 22 of the text of the reprint), and in a drawing by an unknown artist from the DestailCollection, now in the Kunstgewerbe-Museum at Berlin, leur which I hope to publish shortly.

I am now inclined to suppose that it is this arch that is represented in the panorama of Rome from S. Sabina of Anton van den Wyngaerde (Melanges de l'École Française, 1906, Pl. IV-VII), and not as I conjectured in the text (p. 186) the gate leading into the Campo Torrecchiano shown by Heemskerk in two of his views, his large panorama of Rome, and another view of the 
Forum (cf. Lanciani in Bull Com. 1901, 24 ; and ibid., 1888, tav. vii). The representation of the Horti Belleiani is also remarkably fine.

A third edition of our plan, with further modifications to bring it up to date, was published in 1646, with a new dedication. Father Ehrle has discovered a copy of it in the Vatican. There is thus only one copy known of each edition, and these plans are practically original documents. The plans of contemporary Rome by Mario Cartaro are two in number-the small one of 1575 and the large one of 1576 ; the latter being that which (as is expressly mentioned in the text to the restored plan of 1579) he had prepared three years before on the same scale. It is published from a unique copy in the Biblioteca Angelica by Rocchi, Le P'iante di Roma del Secolo XVI, tav. xvi, xvi bis, and pp. $80 s q q$. of the text, and it measures 113 by 91 centimetres, the reproduction being slightly smaller. We must now return to the text and drawings which form the subject of this paper.

The authorship of the work is the great question, to which I cannot attempt to offer a certain solution; but having regard to its close relationship to (and yet slight though important independence from, in some points of detail) the works of Etienne Duperac of Paris, it seems to me not at all impossible that it is to be attributed to Duperac himself.

As we have seen, he was active in Rome at the period to which the drawings must from internal evidence be assigned. The style of the figures in the ornamental borders, which unfortunately are not shown in any of the illustrations to this paper, ought, one would think, to throw some light on the personality of the artist ; but Dr. Hermann Egger, to whose kindness I appealed in the matter, has informed me that he has searched carefully for parallels and been unable to find any. I had the opportunity, however, of submitting the book to Mr. Sidney Colvin, Keeper of the Prints and Drawings in the British Museum, and to Messis. Campbell Dodgson and Laurence Binyon of the same department, and they were of opinion that the style of the drawings was quite consistent with my hypothesis, 


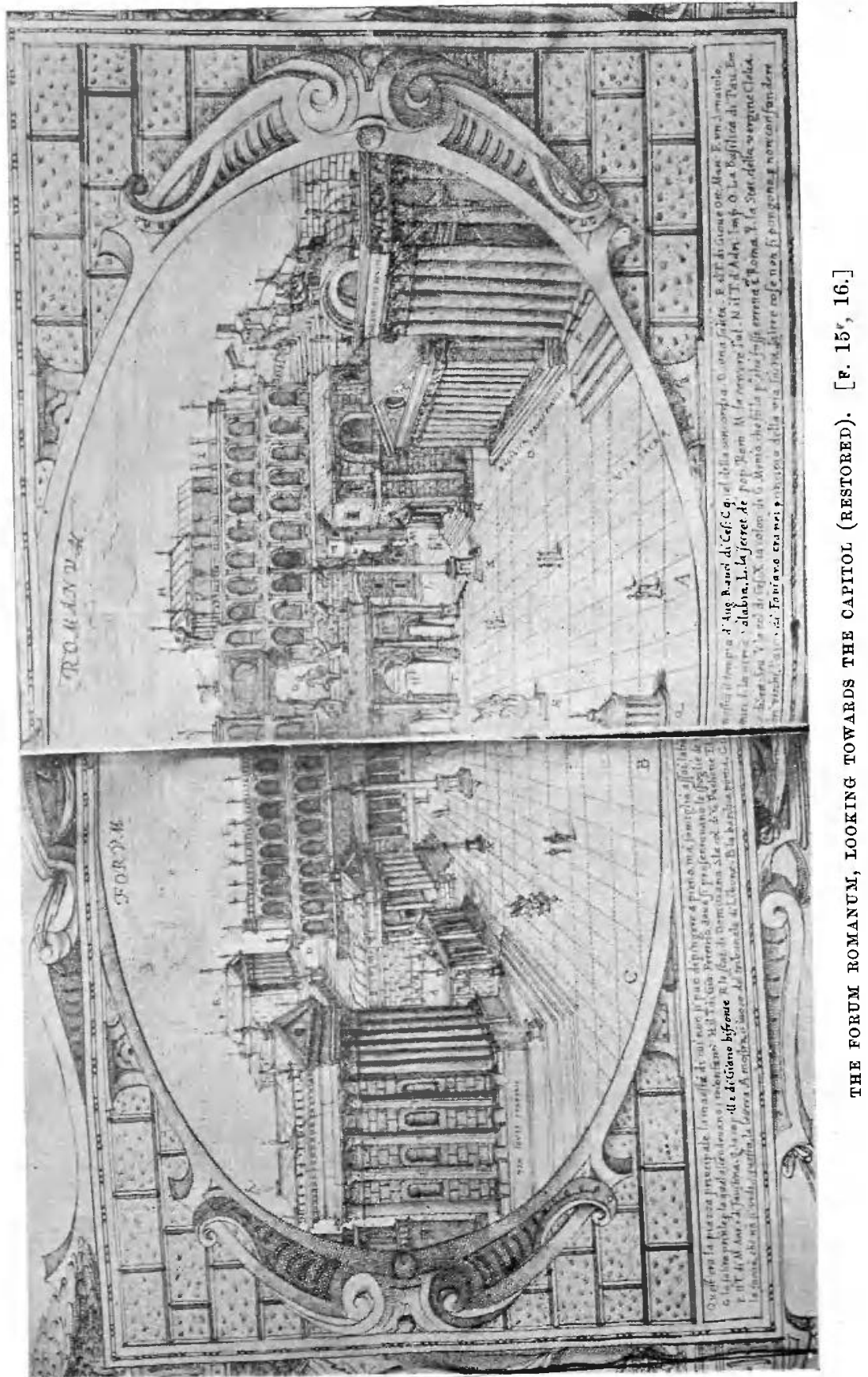


to which they saw no obstacle. The handwriting is too formal to give any decided indication.

I subjoin a short list of the contents of the MS. for handy reference. The original page number is added in brackets, where legible, but it has often been erased. Where it is determinable from internal evidence it is added in square brackets.

f. 1. Title. f. 1v. Blank. f. 2 [34]. Text (gummed to f. 1v).

f. 2v, 3 (35). From Duperac's Sciograpliza, "Villa di I. Rustio" on the left, Pons Aelius on the right.

f. $3^{\mathrm{v}}, 4(41)$. Text, supra, p. 247.

f. $4^{\mathrm{v}}$. View of S. Peter's.

f. 5 (43). Teatro di Belverlere.

f. $5^{\mathrm{v}}$. Blank.

f. 6 (46). Castle of S. Angelo. [Plate I, No. 1.]

f. 6 v, 7 (49). Text, supra, p. 251.

f. $7^{\mathrm{v}}$. The island restored, from Duperac's Sciographia.

f. $8(50)$. View of the island. [Plate I, No. 2.]

f. 8 , 9 (51). Text, supra, p. 251 .

f. $9^{\mathrm{v}}, 10$ [52]. View of the Velabrum, from Janus Quadrifrons to S. Anastasia (left half = Duperac, Vestigii, 12). [Plate II.]

f. $10^{\circ}, 11(54)$. Text, supra, p. 253.

f. $11^{v}, 12[55]$. The Forum Boarium restored, from Duperac's Sciographia.

f. $12^{v}, 13$ [56]. View of the Aventine and the Marmorata (left half $=$ Duperac, Vestigii, 33). [Plate III.]

f. $13^{\circ}, 14$. Text, supra, p. 253.

f. $14^{\mathrm{v}}$. Porta Maggiore (restored).

f. 15 [94]. The Capitol.

f. 15, $16(95)$. The Forum Romanum (restored). [Plate VII.]

f. $16^{\mathrm{v}}, 17$ [967. View of the Forum. [Plate IV.]

f. $17 v, 18$ [97]. The Forum Transitorium (restored).

f. $18^{\mathrm{v}}, 19$ [98]. View of the Forum Transitorium (= Duperac, Vestigii, 6).

f. 19v. Basilica of Constantine (restored). [Plate VI, No. 2.]

f. 20 (99). View of the Basilica of Constantine (= Duperac, Vestigii, 5).

f. $20^{\mathrm{v}}, 21[100]$. The Palatine and Circus Maximus (restored).

f. $21^{v}, 22[101]$. View of the Palatine and the Circus Maximus (= Duperac, Vestigii, 11). [Plate V.]

f. 22 r. Septizonium (restored).

f. 23 [102]. View of the Septizonium (= Duperac, Vestigii, 13).

f. $23^{v}$. The Colosseum (restored).

f. 24 [103]. View of the Colosseum (= Duperac, Vestigii, 16).

f. $24^{v}$. Trofei di Nario (restored), from Duperac, Sciographia (indirectly).

f. 25 (104). View of the Trofei di Mario (= Duperac, Vestigii, 27).

f. $25^{\mathrm{v}}$. The Forum of Trajan (restored), from Duperac, Sciographia.

f. $26(105)$. View of the Forum of Trajan (closely resembles Duperac, Vestigii, 33). [Plate VI, No. 1.] 
f. $26^{\mathrm{v}}$. The column of M. Aurelius (restored), from Duperac, Sciographia.

f. 27 (106). View of the column of M. Aurelius (= Duperac, Vestigii, 34 , left half).

f. 27 . The temple of Neptune (so-called), restored.

f. 28 (107). View of the temple of Neptune (supra, p. 258.)

f. $28^{v}, 29$ [108]. The baths of Caracalla (restored), from Duperac, Sciographia.

f. $29^{v}, 30(109)$. View of the baths of Caracalla ( = Duperac, Vestigii, 19, 20).

f. $30^{v}, 31$ [110]. The baths of Diocletian, restored (slightly altered from Duperac, Sciographia).

f. $31^{\circ}, 32$ [111]. View of the baths of Diocletian (= Duperac, Vestigii, 28, 29).

f. 32v. The Pantheon (restored).

f. 33 (112). View of the Pantheon (= Duperac, Vestigii, 35).

f. $33^{v}$. The Amphitheatrum Castrense (restored), from Dupcrac, Sciographia.

f. 34 [113]. View of the Amphitheatrum Castrense (= Duperac, Vestigii, 26).

f. $34^{v}$. Theatre of Marcellus (restored).

f. 35 (114). View of the theatre of Marcellus (= Dosio, Urbis Romce Aedificiorum quae supersunt reliquiae, 31).

f. $35^{v}$. The Mausoleum of Augustus (restored), from Duperac, Sciographia.

f. 36 [115]. View of the pyramid of Cestius (resembling the engravings of it in Lafreri's Speculum).

f. $36^{v}$. The arch of Constantine (restored).

f. 37 [116]. The statues of Castor and Pollux on the Quirinal (= the plate in the Speculum Urbis Romae, reproduced by Lanciani, Ruins and Excavations, p. 433, fig. 167; Quaritch, No. 199).

f. $37^{v}, 38$ [117]. The Naumachia of Domitian (restored), from Duperac, Sciographia.

f. $38^{\mathrm{v}}$. Blank.

I desire in conclusion to express my great gratitude to Mr. Perrins for having entrusted me with the volume during the winter of 1906-7, thus enabling me to study the drawings in Rome itself, which immensely facilitated my work. 